住过渡时期，资产阶級思㷊与无产阶級思想的斗

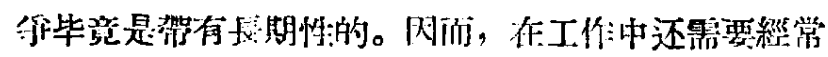
注意拔倣, 插紅旗, 拈能不断取得胜利。

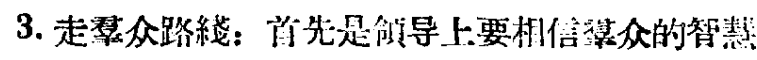

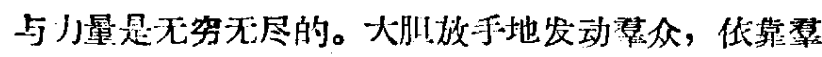

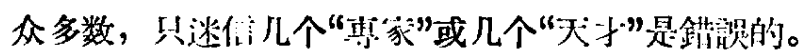
这次跃进中事实証实，有好多“尃家”与“天゙年”認为不

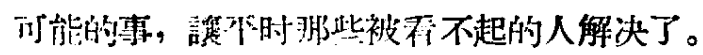

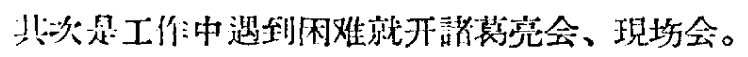
但开会时要以!汾政治三分漟务的精融先务虚再淡 实, 这样, 一些技术上的网难便迎刃而解了。如发光

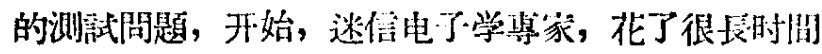

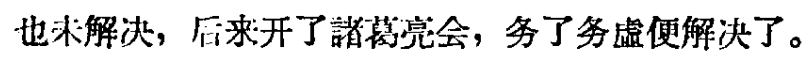

其他的例子还很多，不能一一举的。这也說明了，以

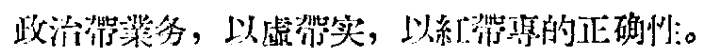

我們知道, 现在作州的这几点工作成就是科学道

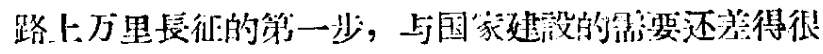

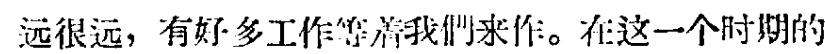

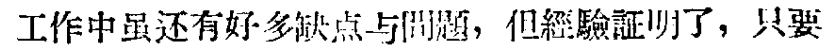

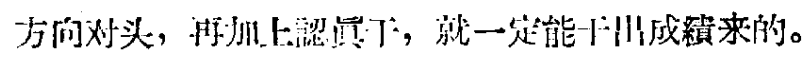
找佃相信总路䋐的力量, 有了总路綫的指导, 就能它

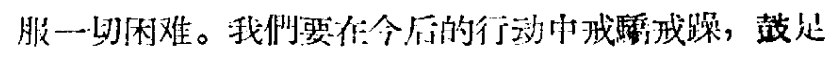

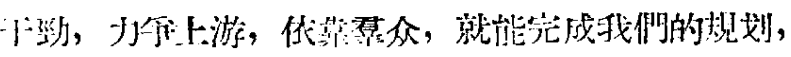
就能使我們所工作氾園內的各項研究工作，迅㳴地

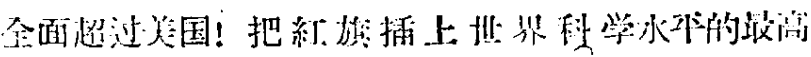
管!

\title{
高举紅旗 征服紅壤荒地
}

\section{成朴 \\ （江西省农菜厅副厅長）}

紅境約上汇酒省土地面积 46\%，主 要分佈在河 谷附近与盆地边緗的丘陵地帶。低代处虽多已开发利 朋，产量一般較低，而絕大部分坡地只生着零星的馬 尾松和稀疏的里草, 其中可农是者約有 1,300 万亩, 相当于全省現有株地面积三分之一。

这些缤色黄紅或深紅的士壤, 解放的虽然有些士 壤学家进行調查工作，但一般仅限于土壤形态的描述 与装些性狀的說吸, 系于紅壤的利用与改造, 这一根 本性閶題几乎汐有研究。科学只有在共产党的创导下 才能得到迅速的发展，才具有人民性与創造性，因 此, 解放初期, 汒西省党政机关就注意到这一閌題, 米吸确提出对开发紅壤荒地进行研究。

1950 年江晒省农科所在接受这一任务时, 技术 力量是相当溥弱的, 没有上壤重業干部, 更缺芝实际 經驗。在研究过程中虽然遇到不少闲难与挫折, 但由

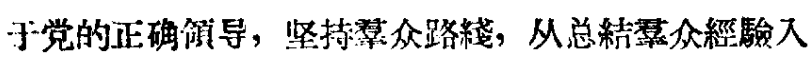
手, 紧䌽結合生产实践, 进行綜合研究, 經过几年来

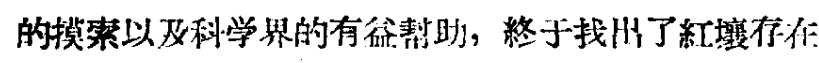
的关䇳問題与解决涂徑。該所从 1950 作开量的 800 亩試驗:基地，逐步扩展到 4,000 余亩。过去只有慕地

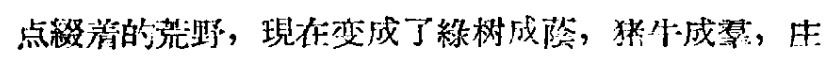
稼崫地，花果滿山的景像了。

这些初步成果, 得到党的高度重視, 汇西省委与

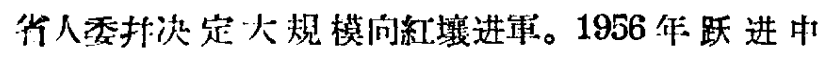

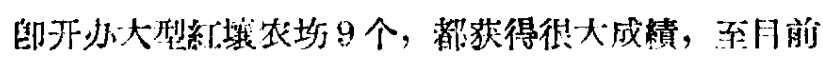

为止,大型农㘯发展到 37 个(县农㘯倘未統計估冈)， 如包括基众开晎的与县农㘯作內, 开旺面积已达 150 余万亩。在大面积开发紅壤中创造了訢多緸驗, 大大

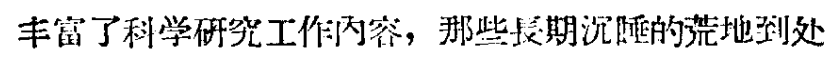

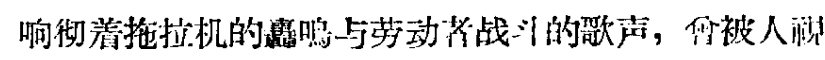
为不毛之地的紅壤正为国芜創造着巨大的財筂。

\section{兩条道路的斗爭}

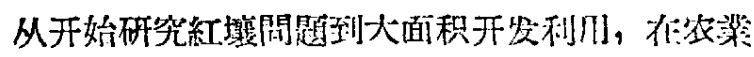
科学界就展开了激烈的斗学。这些斗等集中作：1. 紒. 嫔荒地能不能利用? 2. 升发紅壤从利用着手还是从改 是着手? 3. 开发紅壤是純䉽的土壤閒題还是綜介们农

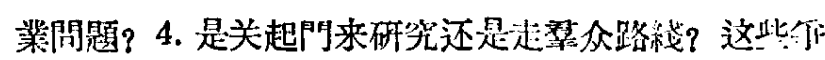

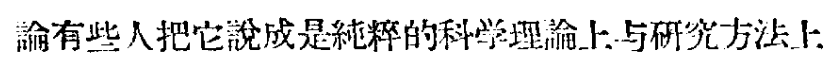
的筈論, 但实質上是: 科学要不要为政治服务、为坐 产服务? 科学研究工作能不能多快好尛? 存派分了.历 来就反对我們这样分析, 訫为党不能邻导科学, 硬馀

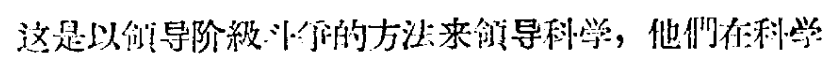
研究上故率玄虚，介图壟断，以反对党对科学的倍

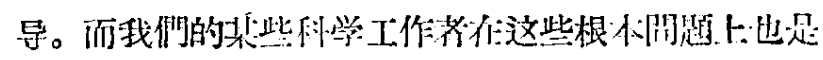

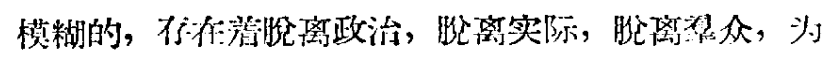

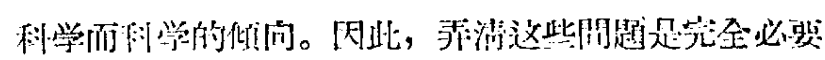
的。

\section{紅壤荒地能不能利用?}

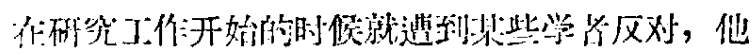


們从肥力递减学說出发, 認为开量紅壤荒地, 会破坏 : t壤。也有人把紅壤看成不毛之地, 認为开暴必定大 欱其本。按留这一論点, 红壤就只能任其荒率, 不能

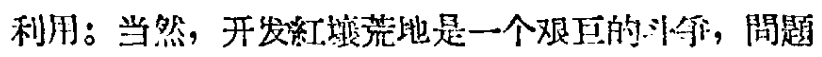
是: 我們是去征服自然呢? 还足甘当自然的奴隶? 根 本润题还在于他們实啠上否認人的劳动对士壤的积极 影响。我們認为: 人的辛勤劳动, 不仅叮以光分发纬

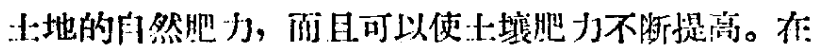

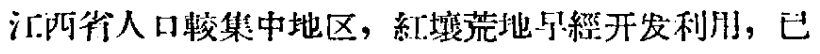

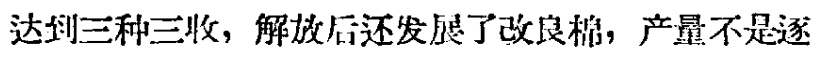

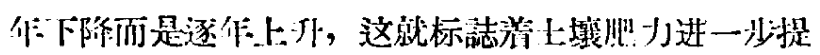

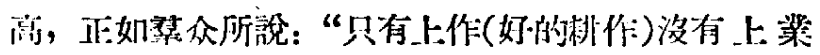
(好的1:地)”。我們認为这是劳动人民作生产实践中 所获得的极为宝贵的科学結涂。

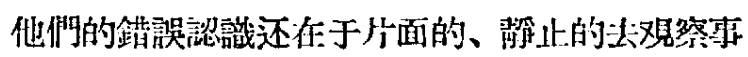
物, 缺乏黑列主义的分析方沾。紅壤的铃痛現狀, 固 然有其发生学上的因等, 但也有社会的因素, 特别是 近几十一作反动統治的結果。他們只看到自然条件不利 的一面, 而沟有程琲优越的一面(面且是主要的一 面)。在溫暖湿潤的气候条件下，有机質分解快，但 形成也快, 美分淋失快, 但积新也快。他們把开发紅. 壤荒地理解为天然肥沃性的块, 而看不到人为肥沃 性的提高。实践证明：合理利用紅壤就能抑制地質循 环作用, 打强生物的循环作用, 人的能动性就是在于 利用与发掩有利的因素, 限制与改造不利的网濝。阶 級斗争如此，生产斗孚也如此。

\section{从利用着手还是从改硍蓎手?}

这一關題等論很久, 㨁至 1957 年还有人坚持先 改良后利肪的主張。他們把改良与利为完全机栰的制 裂开来, 涊为“不改主就无法利用”。如相照这种理論 去开发紅壤荒地, 势必投資大, 收效慢, 这显然是脫 离实际, 脫离㻎众, 瞈离生产的覌点, 是与多快好省 相違韭的。我們涩为利用与改良是对立的, 又是統一 的, 应該是, 也必須是从利俆着手，边利用，边改良。 更确切地說, 就是从生产撯手, 通过合理利 月月(生产 汒尔)改良土壤, 达到发展生产的目的。实践証明: 生产发展的过程就是七壤逐少改良的过程。土壤的改

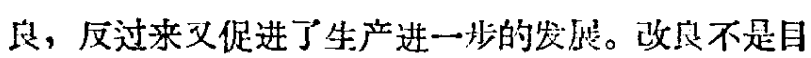
的, 絕不能为改艮而改良, 只有生产于是目的, 土壤 改主主是发展生产的結果。

改良諭者主張，“起初几年种犆多作生的豆科或禾

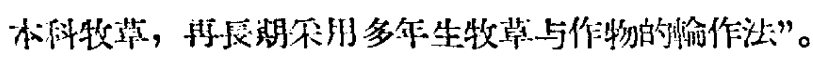

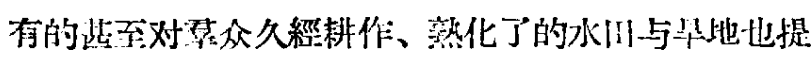

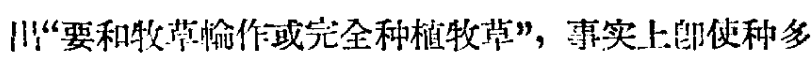

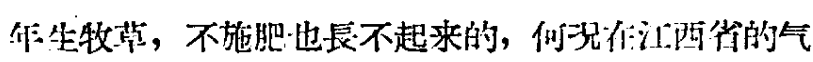

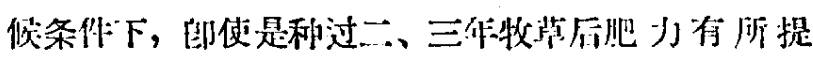

高, 一經翻排, 也是不能維持多久的。如果尔风落田

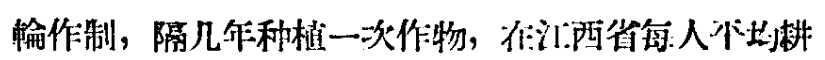
地不及 2.5 亩的恬况下, 既不应該, 也不可能策取这 种作法，而且汇西省大部地区历来就有冬播粶肥的輸

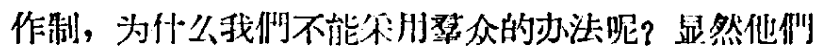
既沟有洘虑当地的具体条作, 也无視于下百作来农上 創造的丰富經驗。

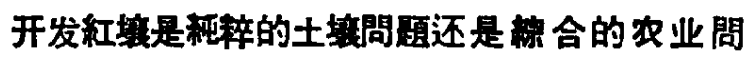

\section{道?}

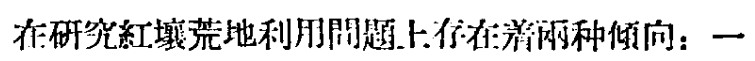

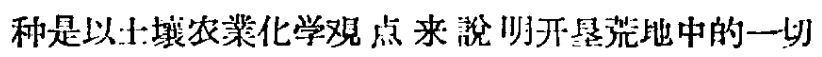

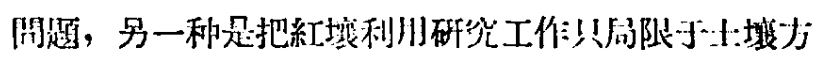

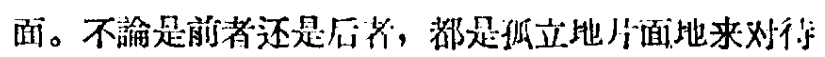
这一問題, 而没有認識到事物的闪仁联系。我仙洒为 开悬紅壤不是一个單純的土烄閒題, 而是一个綜合的 农業問題。

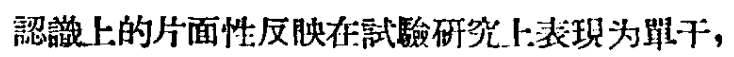

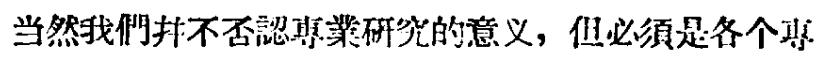
菜互相协作的基础上进行, 否则的使做证，一些成績, 那也只能解决开发紅堆中个别閏題或枝节問題。我侧 正由于坚持从生产肘发, 进行称命研觉, 因而找䶺了 农林牧綜合利用的措施, 同时也大大綰短了研究过 程。不仅研究紅境应該如此, 研究一切农業科学閌题 也应該如此。

必須指出，㷊些技术干部不仅在認裁上你在片面 性, 而且也隐藏着或多或少、或归或蔀的个人打算。 他們拒絕合作，各搞一瓷，呪等將资料据为已有，介 图个人成名成家。这些思想如不改变, 既不利于㼛全 主义建設，也不利于自己的思悡改造。当然，在經过 全民整风与反右后，牌能得到逐少改变。

\section{是关門研究, 还是走群臬路線?}

在科学研究工作中, 这是一个长期沒有彻低能决 的問題。少数科学技术人日涊为科学䃟究工作不一资

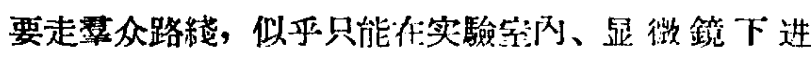
行。他們看不見鼻众智慧，輕視生产实践所积累的經

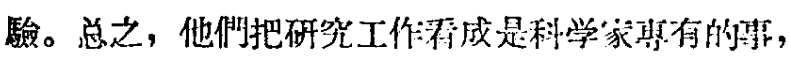

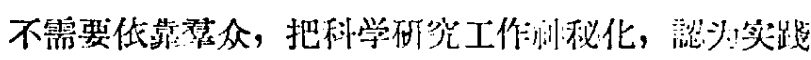

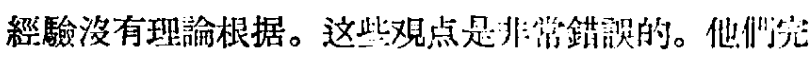
全不了解科学理論乃是劳动实践經驗的总結与提漓,

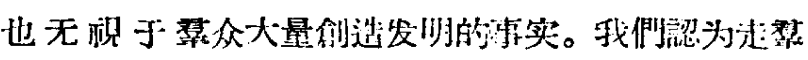
众路綫是做奵一切工作的根本方邻, 少农科所紅境研 究工作初期的挫折就証㫬了这一点。阅然当时技术

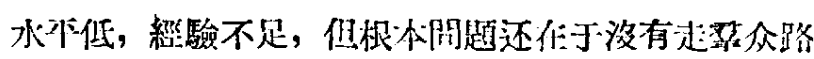
綫。这一偏向及时紏正后, 近过不断总絬瑟众經驗, 結合坐产进行綜合研究，研究工作就得到进速发展。

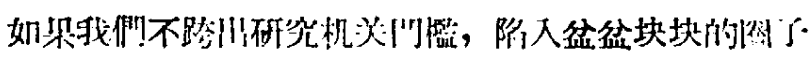


內，是不可能在短时期內提出农林牧相結合的綜合措 施的。

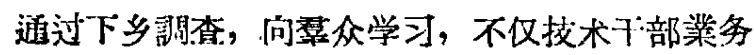
上得到提高，而目在思想上世得到很大䤮鍊，从而保 証研究工作的顺利开展。四此, 紅壤研究工作的成 功, 就是党的㥒众路綫的胜利。

\section{紅坮荒地利用中的几个关鍵}

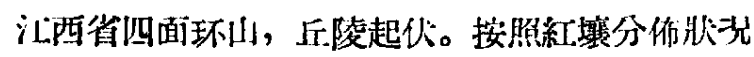
可划分为三区, 印: 山地紅聂区、高丘陵縕壤区与低

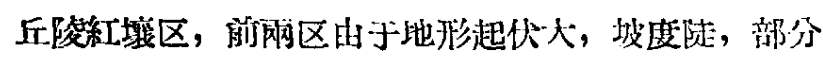

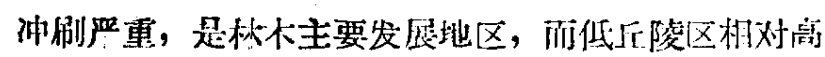
度均在 50 公尺以下, 坡度本緩, 士层深厚, 而目面

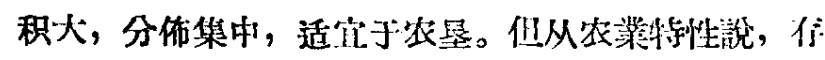
仁的缺陷是: 有机筫缺芝, 酸性强, 代揬量低, 保水 保肥力弱, 植物营养元素含量少, 耕作性能坏。扣之 丘陵地形植被复盖度小，易蚶刷出易下些。这些特 性, 在影多文献都分别阔述过, 但什么是最基体㧐主 要的缺陷呢? 如们从利为着手进行改造呢? 这是紅㳖 开悬中首先要解次的实际問題。

\section{关鍵在于提高土壤有机留}

紅筫是温暖湿㳱条件下形成的, 出物作汌与化学 作H诗很强烈, 不仅有机物分解快, 矿物分解比比较

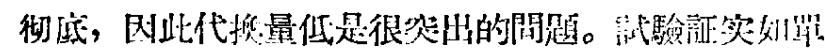

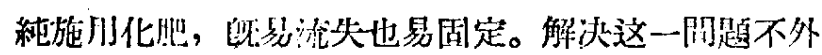

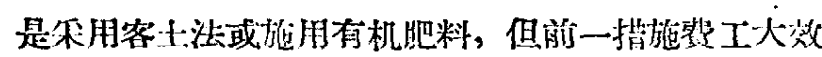
果小，而后一猢施則可事牛功倍。从理諭上說, 在

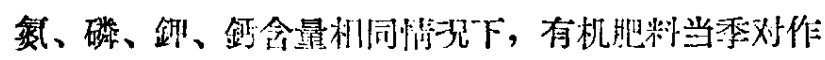
物效果不及无机把料，促部多侙驗証朋有机肥料比无 机把料好, 这就清楚看淮有机肥料在紅壤上施用的优

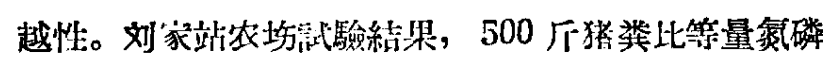
化肥，黑麦籽实要增产 8 倍。汇西省农菲科学研究所 施用綵肥也获得增产效果, 有的䓕至增产一倍以上。

有机肥料的作:月月, 不仅装現在对作物产量的提

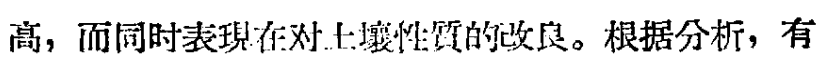

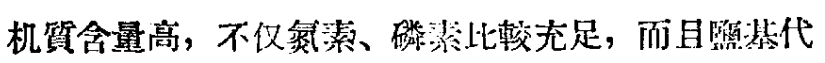

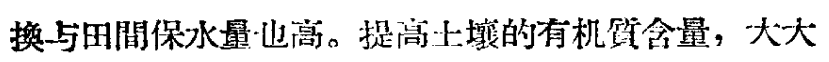

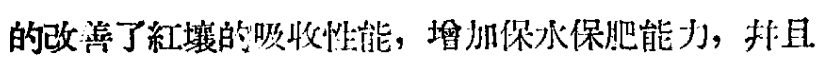
提高了植物营养元渠的有效度。因此, 施丽有机肥料 是开发利用紅培帶根本性的关鋌措施。一

为了增加有机肥料的来源, 除了养猪积肥, 制造 嫶肥外, 还可以任輸作中安排冬季線肥, 井利肘零星

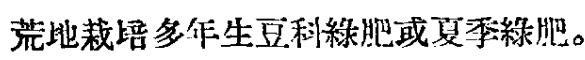

我們强谓有机肥料作用, 扭不排除无机地料的施 用, 很多韧驗証攸; 在有机肥料中混合无机肥料, 优 越性更入，但从改良士壤效果看：有机肥料始終优于
无机肥料。因此, 在农業生产中, 保証作物产量的不

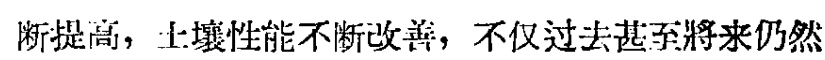

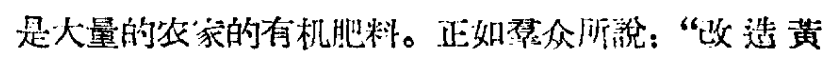

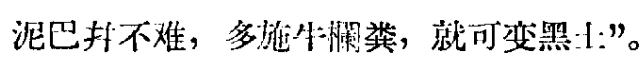

叠众任利用紒壤中广泛施用草水灰。这样比订中

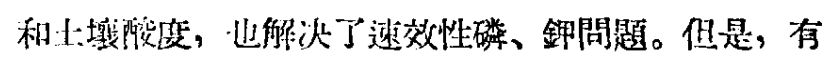

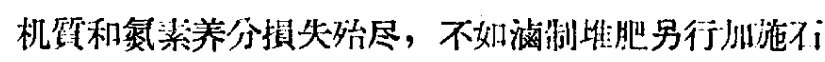

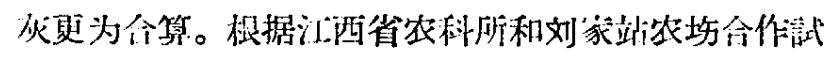

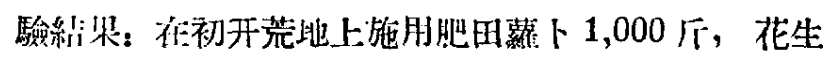

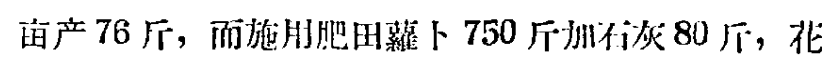

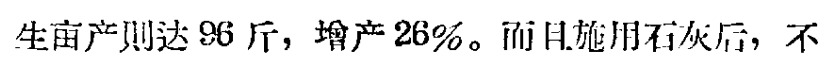

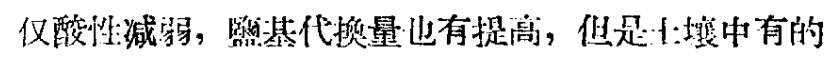

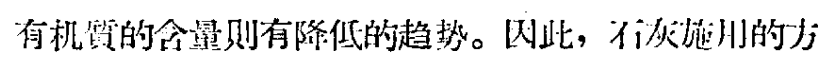
泣是量多次少? 还是量少次多? 还值得进一少研究解 炕。

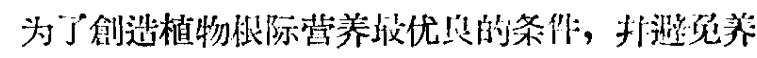

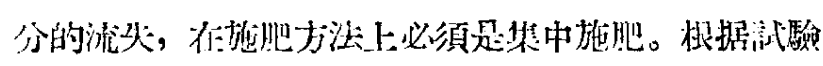

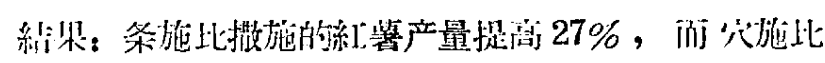

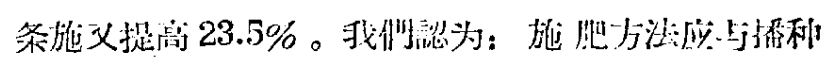

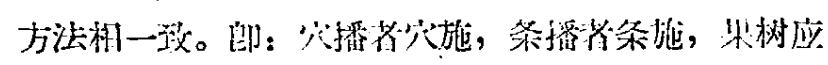

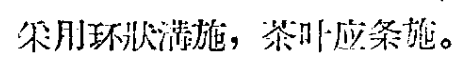

\section{选擇耐濡、耐酸、耐旱的先鋒作物}

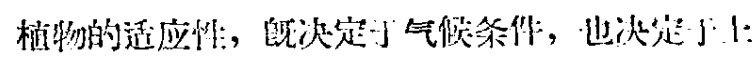

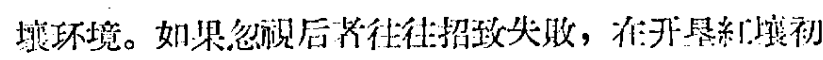

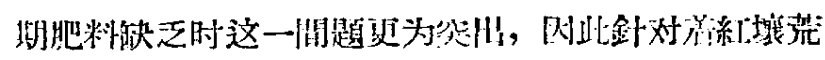

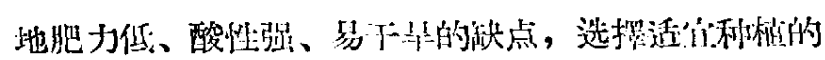

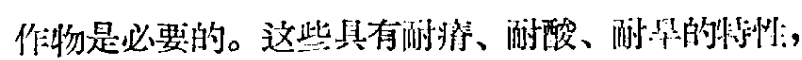
在开是初期能获得订雚产量的作物就称为光鉖作物。

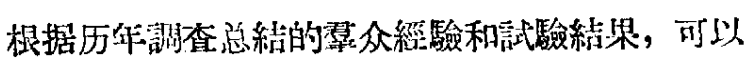
做为先鋒作物的，以紅學、花生、子瓜、朴箸、黑麦

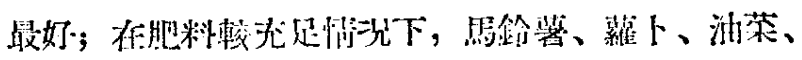

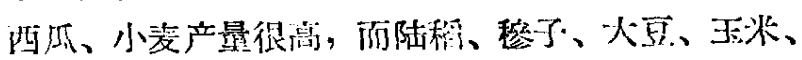
科花、大麦则需要更多的肥料和光足的水分, 如这些

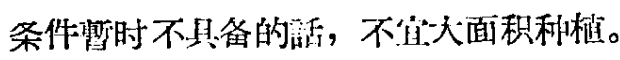

同一作物，不闬品种的适应性:能也表現不一玫。

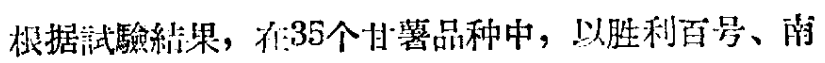

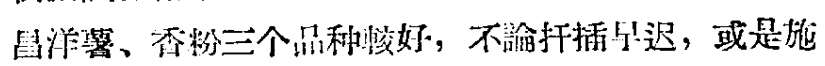

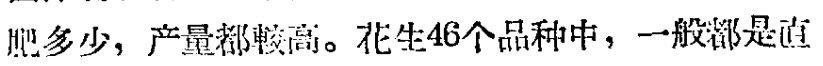

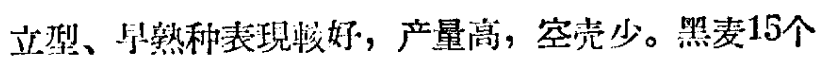
品种中，以裹阳烸麦最为适宜。

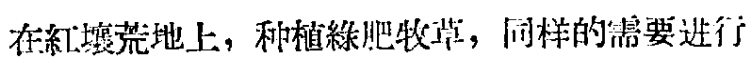
选擇, 才能有是奵的收成。我們涊为越作生冬季線 肥, 是应該重視的, 不占主要农事季节, 对提高士士壤

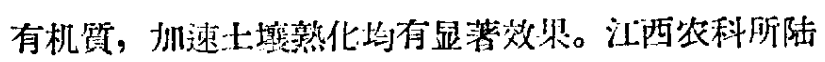
續引种 125 种牧草, 試种多年的結果, 在初是荒地

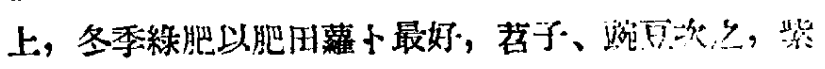




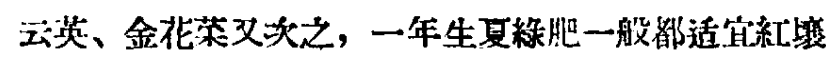
裁培,但大多数木资化严重,部分結实网难。其中表現 較好的是：單叶猪屎豆、狗爪豆、飯丟、鵎眼草。多 年生粶肥牧草，以知风草、黑麦蔡、䕀藤、湖枝子最

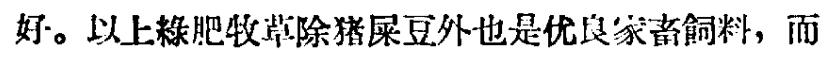

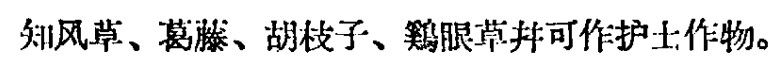

以上一年生作物与越年生冬季綠肥 叮配成 以紬 警、花生为主的輪作制度。但是在开是初期, 肥料不 足水源不好的情况下，复种指数不宜过高。根据試驗 結果, 每年一季作物, 一季株肥或柃料, 产量高, 投 資少, 盈利多, 如棵一年三种三收, 在荒地未第化前, 从經济上来考虑是不划算的。

关于多年生經济作物与經济林木的种类，根据装

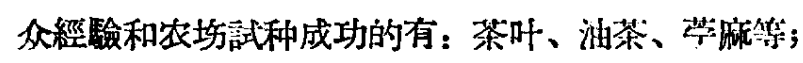

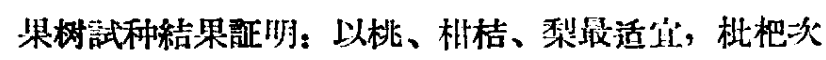
乙。

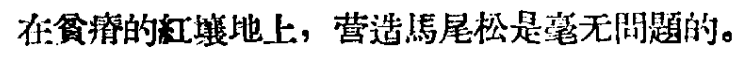

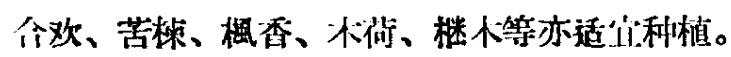

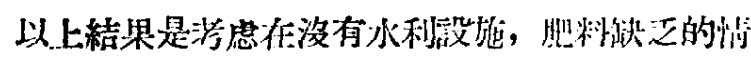
况进行的, 在大跃进形势下，根据少体条作，佂选提 光䣄作物方面当有更大发就。

\section{防止冲刷, 克服千早}

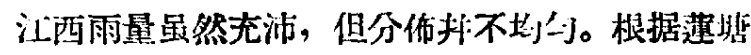
气候端 1947-1955 九年的統訫，本坋华降雨量是 1703.5 公四!，但有 58.2\%集中在 3-6 月, 且前期多 后期多暴雨。7 7 月以后, 轉为草季, 特别是

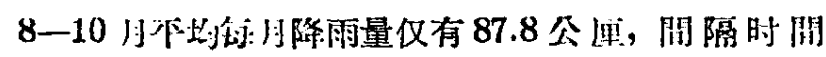

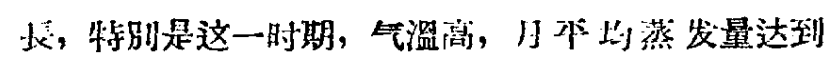
211.2 公厘。如果不尔取措施，不仅是季降雨入不數

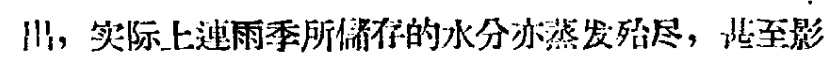
吻冬季播种。显然冲刷与千草, 是一刘變生子, 如果 禾取棕合措施, 就能闹时得到解决。

这一閐題首先在开荒时就要注意, 如果策州順坡 耕种证至从坡脚到坡镍全部翻耕, 不仅机械效率低耗 油入，而目人为造成冲浘，裴士流失，㨁接影响产

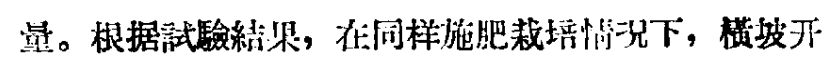

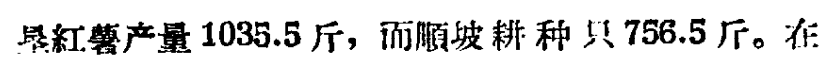
坡度 10 度以上应作等高梯地, 10 度以下约可等高培

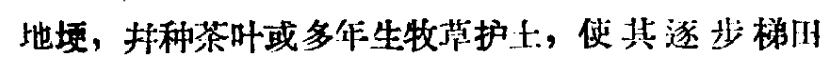
化。

开荒时絬合的間道路规划，从坡嶺至坡距保留等: 高緩讵草带，特别是坡嶺造林結合种植多年生牧莒， 此植被稀少的荒地逕流流量与冲刷量降低五倍后不， 而上壤湿度要提高二分之一。

开荒时期的选摆, 从洘虑沖刷与平早問題红发, 以秋夏之交(郎早季前)比較合适，开晎后䚀不种㥀，

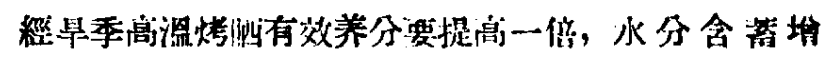
抓, 四此比冬季随开随种作物 要增产 71-97\%, 如信季开量随开随利比栦活不利水上流灼要减少 $20-40 \%$ 。

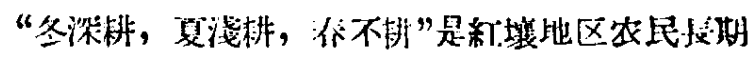

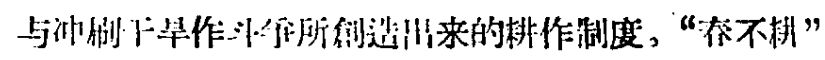

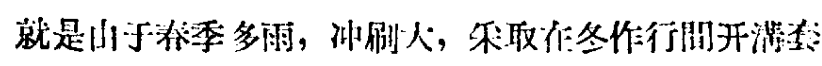

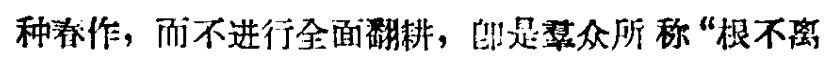

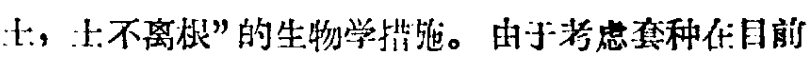
惯况下不易机株, 因此江邽农科所改变成青对或收制 冬作后隔一等距离留茬播种，根据测资，不闰农栄指 施对防止水土流失的效果, 以等鬲留茬与等高作钺效 果樶好，能减低流速，分散湮流。目此我們認为宽行

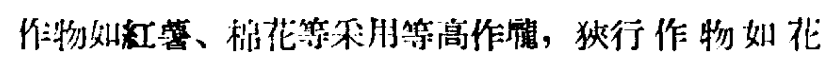
生、飯㱖等的柇用等高留萑。

“冬深粦”是糽境坡地提高产量的主要环节, 既利

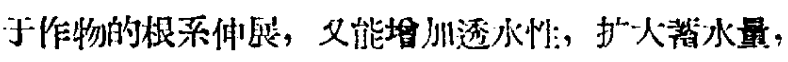

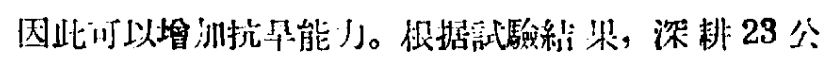
分比淺样 10 公分, 紅等增产较显蓄。如果排作层进

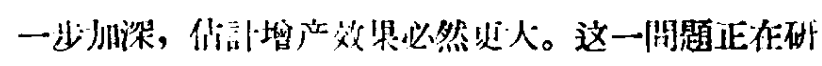
究中。

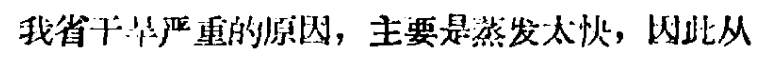

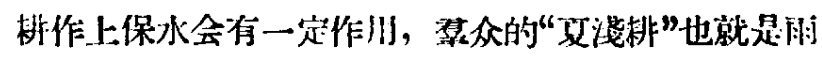

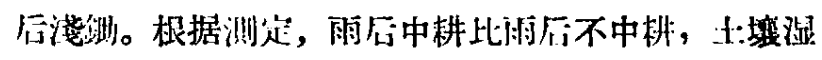
度一般能提济五分之一。此外，从作物方面选用呈熟

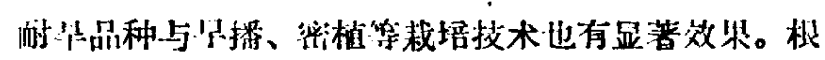

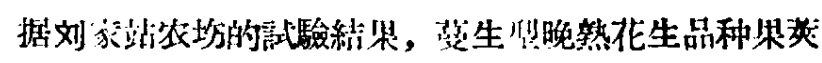

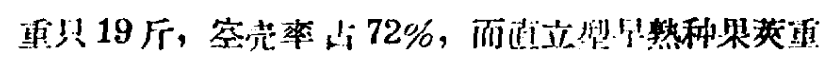

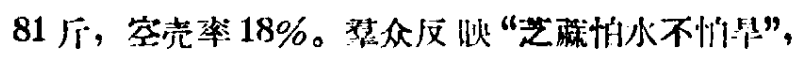

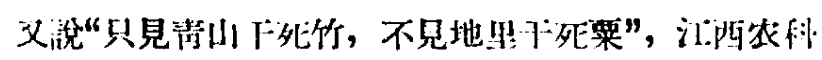

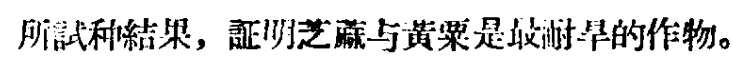

江西农科所在总結生产中发現了实行提罗!括种，与

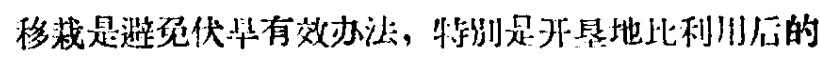

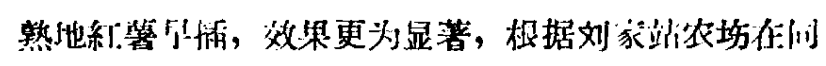

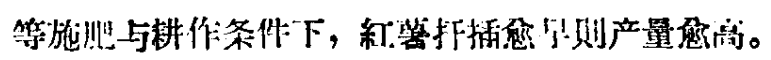

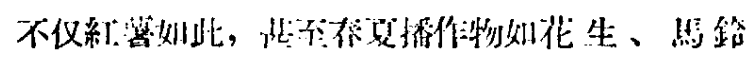

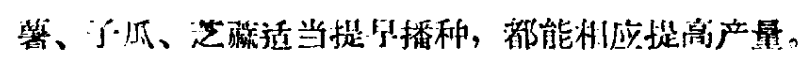

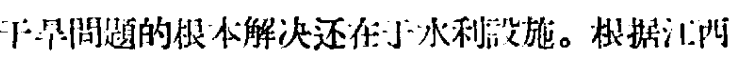

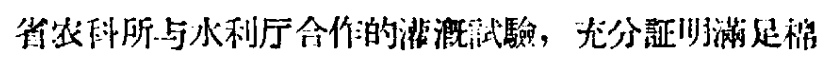
花水分需要后，产量要提高 5 倍。虽然后陵地区多被

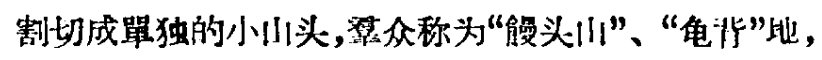

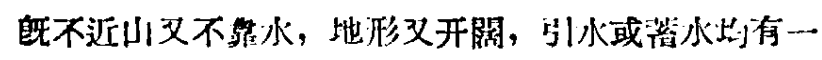

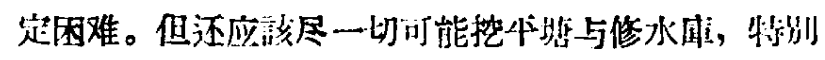

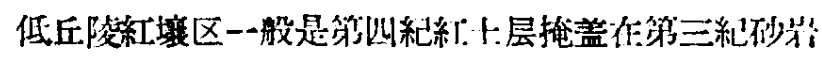
上., 你这二个地层之间, 很往有一层粗砂或磁不层,

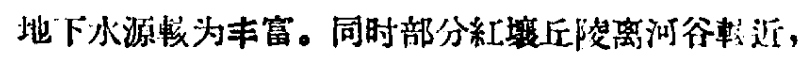

486 
因此打井灌激有很大发展前途。此外，結合水正保持 工作时在排水核附近修筑很多狄口深池, 春夏季能落 水, 减少婳流量, 秋季可抗早, 爸季与星春还可作积 肥现，一举三涹，投資少，收效快。

\section{全面規划，綜合利用}

低厅陵紅壤区蛙于沉积与侵触的情况不一，士层 卓度坡度大小边不尽闹，上下坡肥力很不一致。根据 以上情况, 投洘虑到植物根系深淺, 对肥力与耕作裂 求全面规划是縕壤荒地利用的宁要环节。一般說: 下 坡宜和一年生饻作物与鸰料作物，上坡㙂种土果树、

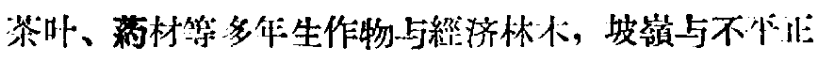

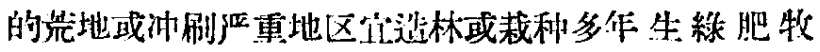
节，坡度較小 $(8$ 度以下 $)$ 上层較薄地区应以发展农倠:

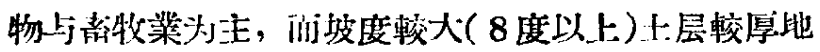
区应发展多年生經济作物与林木为主, 但不論經营主 要菲务如何, 就林牧副必須絬合, 没有这种結合不能 达到投資少, 收效快, 收径大的要求, 特別是沟有这 种絬合也不可能解决有机肥源、沖刷与个早間題。因 此这种結合不仅是一个农浆經营的原则間题, 也是綜 合利月紅壤的根朴间題。

綜合利为结种經营的璂础是农牧的結合，只有邻 料与肥料的解沙, 农箱生产子有叮能获得迅速的发 bin.

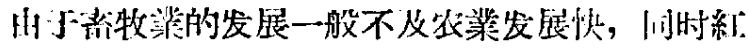

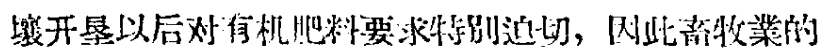

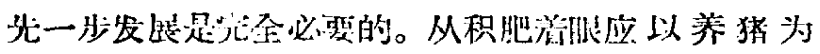

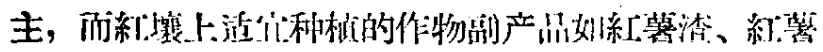

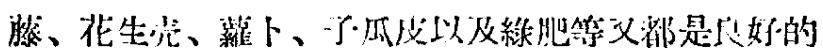

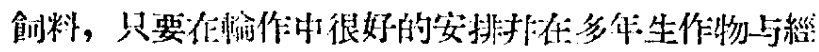

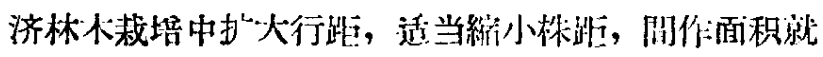
能增州。

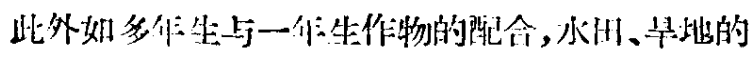

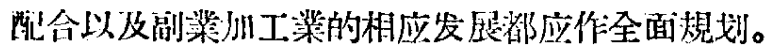

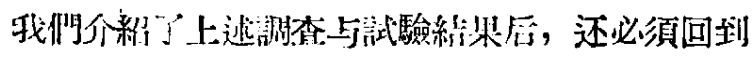

前面所奇論的間題.上来, 因为事实最具有說服力。

从汇西农科所示沾农㘯历年作物产量看，在初量

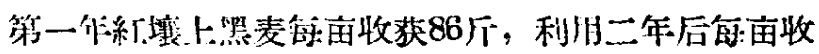

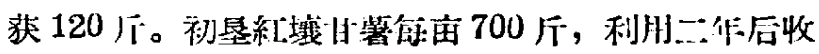
获 1,200 斤,利用三华后收获达 1,380 厅。花生在开悬 当焦只收92厅，利13三年就达到203厅。据1957年生产

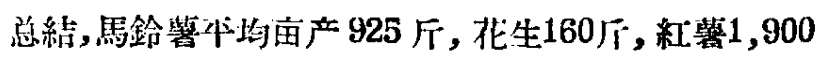

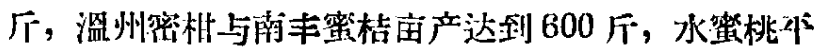
均宙产 500 斤。

作物产量的增的就标志地力的提高。根据农科所

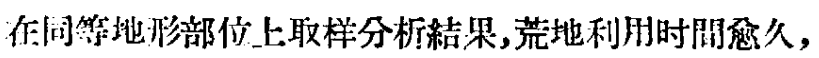
肥力愈高, 事实駁倒了那种認为利用紅壤就会破坏: 壤的論断，也駁倒“必須先改良后利用”的覌点。

还有人認为, 利肋这样貶凊的紅壤必定会大玲其 小，根据农科所示氾农㘯柏南分坊从 开办的 1957 作 收文情况看, 这种担心是沒有根据的。該坋1952年开 办，1953年收支接近本衡，1954年郎有盈余，純收入 逐作增加，不仅为脚会主义創造了財䈏，还上移了利

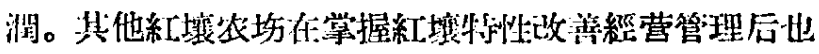
嘟得到盈余。

紅壤研究还仅仅是一个开端，部多間題如水利、深

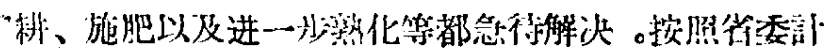
划, 到1962作就要开悬 850 万亩糺壤洸地, 任务也是

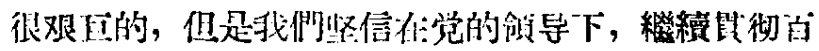

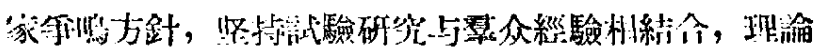

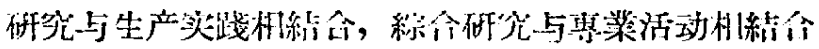
的方針, 就一定能师速科学事業的发是。特物作总路

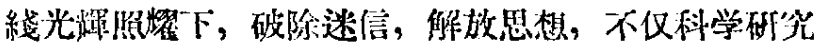

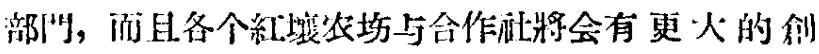
造。汭西农科所的經驗是在一定的条件下摸 采油来 的, 当然有很大参考价值, 但是决不要局限在这些鹏 題上, 而箩要进一步发展。只要各方面通力协作，百. 相促进，就一定能提前实現开发紅壤的作务，就一定 能把紅壤流地变成回稼遍地，花果滿山。

\section{大面积塱殖利用紅壤的初步經驗}

\section{張、毓 敏}

（江西国营刘家站綜合星㥀㘯第一副㘯长）

\section{一 㘯区自然条件与基本情况}

刘家站紜会旺殖㘯位于江西上篦猄区余江县, 以 渐錚鉄路刘芜事站为中心，是一方低后陵紅壤地区。
坋区地势体緩, 坡度一般为 $2-3$ 度,荒地联片集中, 据勘測䙺划农悬荒地的有十万余亩。当地气侯溫和， 全年不均气溫为 $18.2^{\circ} \mathrm{C}$ ，无 箱期長达 270 余天，年 降雨量壮㘬在 2,200 毫米, 但祙点是雨量分布不均, 